\title{
EVALUASI PENATALAKSANAAN PROGRAM PENGELOLAAN PENYAKIT KRONIS (PROLANIS) DI PUSKESMAS KOTA BENGKULU
}

\author{
Avrilya Iqoranny Susilo $^{1)}$, Satibi ${ }^{1)}$, Tri Murti Andayani ${ }^{2)}$ \\ ${ }^{1}$ Prgram Studi Farmasi, Poltekkes Kementerian Kesehatan Bengkulu \\ ${ }^{2}$ Fakultas Farmasi, Universitas Gajah Mada Jogjakarta \\ E-mail: ranny.bengkulu@gmail.com
}

\begin{abstract}
Problems: Health Chronic Disease Management Program (Prolanis) BPJS Health as a system of health services and proactive approach implemented in an integrated manner involving participants, health facilities and BPJS Health becomes an important factor because it becomes one of the indicators of the fulfillment of the commitment of service at puskesmas. The Aim Of The Research: This study aims to determine the management of Prolanis which includes membership, activities, availability of drugs and availability of funds Prolanis, knowing the barriers to the implementation of Prolanis and know the ratio of visits and quality of life of participants Prolanis. Research Method: The research was conducted by descriptive method through interview technique, check list and WHOQoL questionnaire for quality of life measurement. Data retrieval used primary data by interviewing 40 informants and filling questionnaire on 262 participants of Prolanis. The secondary data was obtained from P-Care Puskesmas application. Analysis of the results of research was using descriptive analysis with narrative exposure accompanied by data tables. The Results: The results showed that from 20 Puskesmas 1 Puskesmas had not fulfilled the minimum requirement of Prolanis formation, 4 Puskesmas had not conducted gymnastic and educational activities, 2 Puskesmas did not implement pharmacy service standard for drug distribution Prolanis and 4 Puskesmas had not utilized Prolanis fund provided by BPJS Kesehatan. Conclusions: $50 \%$ in some puskesmas cause puskesmas to be in unsafe zone for assessment of capitation indicator. For measurement of quality of life of participants Prolanis obtained 95, 04\% of respondents have good quality of life.
\end{abstract}

Keywords: Prolanis, puskesmas, indicator of capitation

\begin{abstract}
ABSTRAK
Permasalahan:Program Pengelolaan Penyakit Kronis (Prolanis) BPJS Kesehatan sebagai suatu sistem pelayanan kesehatan dan pendekatan proaktif yang dilaksanakan secara terintegrasi yang melibatkan peserta, fasilitas kesehatan dan BPJS Kesehatan menjadi faktor yang penting karena menjadi salah satu indikator kapitasi berbasis pemenuhan komitmen pelayanan di puskesmas. Tujuan Penelitian:untuk mengetahui penatalaksanaan Prolanis yang meliputi kepesertaan, kegiatan, ketersediaan obat dan ketersediaan dana Prolanis; mengetahui hambatan pelaksanaan Prolanis serta mengetahui rasio kunjungan dan kualitas hidup peserta Prolanis. Metode Penelitian:Penelitian dilakukan dengan metode deskriptif melalui teknik wawancara, checklist dan kuisioner WHOQoL untuk pengukuran kualitas hidup. Pengambilan data menggunakan data primer dengan wawancara terhadap 40 informan dan pengisian kuesioner pada 262 peserta Prolanis.Sedangkan data sekunder diperoleh dari aplikasi P-Care puskesmas.Hasil: Analisis hasil menggunakan analisa deskriptif dengan pemaparan berupa narasi disertai tabel data. Hasil penelitian menunjukkan dari 20 puskesmas 1 puskesmas belum memenuhi persyaratan minimal pembentukan Prolanis, 4 puskesmas belum melaksanakan kegiatan senam dan edukasi, 2 puskesmas tidak melaksanakan standar pelayanan kefarmasian untuk pendistribusian obat Prolanis dan 4 puskesmas belum memanfaatkan dana Prolanis yang disediakan BPJS Kesehatan. Kesimpulan:Rasio kunjungan dibawah $50 \%$ di beberapa puskesmas mengakibatkan puskesmas berada di zona tidak aman untuk penilaian indikator kapitasi. Untuk pengukuran kualitas hidup peserta Prolanis diperoleh 95,04\% responden memiliki kualitas hidup yang baik.
\end{abstract}

Kata Kunci:Prolanis, puskesmas, indikator kapitasi 


\section{PENDAHULUAN}

Fasilitas kesehatan tingkat pertama (FKTP) atau fasilitas kesehatan primer merupakan ujung tombak dalam pelayanan kesehatan kepada peserta BPJS Kesehatan. Untuk meningkatkan peran dan fungsi tersebut, maka kualitas fasilitas kesehatan primer sebagai gerbang utama pelayanan kesehatan perlu diperkuat. Dalam rangka peningkatan mutu pelayanan FKTP diberlakukan pengembangan sistem pengendalian mutu dan sistem pembayaran melalui norma penetapan besaran tarif kapitasi dan pembayaran kapitasi berbasis pemenuhan komitmen pelayanan. Pemenuhan komitmen pelayanan dinilai berdasarkan pencapaian indikator dalam komitmen pelayanan yang dilakukan FKTP yang meliputi Angka Kontak, Rasio Rujukan Rawat Jalan Kasus Non Spesialistik dan Rasio Peserta Prolanis rutin berkunjung ke FKTP (BPJS, 2015).

Pusat kesehatan masyarakat (Puskesmas) merupakan FKTP milik pemerintah yang melaksanakan program pengelolaan penyakit kronis (Prolanis). Prolanis adalah suatu sistem pelayanankesehatan dan pendekatan proaktif yang dilaksanakan secara terintegrasi yang melibatkan peserta, fasilitas kesehatan dan BPJS Kesehatan dalam rangka pemeliharaan kesehatan bagi peserta BPJS Kesehatan yang menderita penyakit kronis untuk mencapai kualitas hidup yang optimal dengan biaya pelayanan kesehatan yang efektif dan efisien (BPJS, 2014). Prolanis menjadi salah satu indikator penilaian kapitasi berbasis pemenuhan komitmen pelayanan di puskesmas. Setiap puskesmas harus memenuhi target rasio kunjungan Prolanis yang ditetapkan untuk pembayaran kapitasi. Untuk mencapai target yang telah ditentukan oleh BPJS Kesehatan maka puskesmas harus secara aktif dan berkelanjutan melaksanakan berbagai aktivitas layanan Prolanis. Aktifitas dalam Prolanis peserta BPJS Kesehatan meliputi aktifitas klub seperti senam Prolanis, konsultasi medis, edukasi, home visit, reminder melalui sms gateway dan pemantauan status kesehatan. Kegiatan Prolanis ini sangat besar manfaatnya untuk kesehatan pasien-pasien kronis,tetapi dalam pelaksanaannya di puskesmas masih banyak ditemui kendala. Untuk itulah perlu dilakukan penelitian untuk mengetahui penatalaksanaan Prolanis yang meliputi kepesertaan, kegiatan, ketersediaan obat dan ketersediaan dana Prolanis; mengetahui hambatan pelaksanaan Prolanis serta mengetahui rasio kunjungan dan kualitas hidup peserta Prolanis.

Penyakit kronis merupakan permasalahan kesehatan serius dan penyebab kematian terbesar di dunia.Penyakit kronis menyebabkan kematian pada 36 juta orang di seluruh dunia atau setara dengan $36 \%$ jumlah kematian di dunia.Berdasarkan hasil temuan Riskesdas pada tahun 2013, penyakit kronis merupakan sepuluh penyebab utama kematian di Indonesia (Kemenkes, 2013).Pengelolaan penyakit kronis ini merupakan prioritas penting bagi setiap 
negara yang ingin meningkatkan kualitas hidup warganya dan mengurangi beban pada sistem perawatan kesehatannya. Di semua negara baik yang berpenghasilan rendah, menengah maupun tinggi rata-rata 50-80\% dari anggaran kesehatannya dihabiskan untuk perawatan penyakit kronis (Singh, 2008).Pengelolaan penyakit kronis ini diharapkan dapat meningkatkan kualitas hidup, meningkatkan outcome kesehatan, meningkatkan kesehatan mental dan pengurangan pemanfaatan fasilitas kesehatan.Pengelolaan penyakit kronis yang dilaksanakan di fasilitas kesehatan primer untuk perawatan DM dan hipertensi memberikan hasil yang positif dan sangat berguna untuk pengambilan keputusan klinis (Stellefson, 2013).

Program Pengelolaan Penyakit Kronis (Prolanis) merupakan upaya promotif dan preventif yang dilakukan oleh BPJS kesehatan.Salah satu tantangan BPJS Kesehatan adalah memastikan Prolanis menjadi program yang mampu meningkatkan efisiensi dan efektivitas Jaminan Kesehatan Nasional (Idris, 2014). Artinya, Prolanis tidak saja harus mengedepankan peningkatan mutu pelayanan kesehatan, namun di saat yang sama Prolanis juga harus mengedepankan pengendalian biaya pelayanan kesehatan (Dennis, 2008). Prolanis adalah suatu sistem pelayanan kesehatan dan pendekatan proaktif yang dilaksanakan secara terintegrasi yang melibatkan peserta, fasilitas kesehatan dan BPJS Kesehatan dalam rangka pemeliharaan kesehatan bagi peserta BPJS Kesehatan yang menderita penyakit kronis untuk mencapai kualitas hidup yang optimal dengan biaya pelayanan kesehatan yang efektif dan efisien. Tujuan Prolanis adalah mendorong peserta penyandang penyakit kronis mencapai kualitas hidup optimal dengan indikator $75 \%$ peserta terdaftar yang berkunjung ke fasilitas kesehatan tingkat pertama memiliki hasil "baik" pada pemeriksaan spesifik terhadap penyakit DM Tipe 2 dan hipertensi sesuai panduan klinis terkait sehingga dapat mencegah timbulnya komplikasi penyakit (BPJS, 2014).

\section{METODE PENELITIAN}

Penelitian dilakukan dengan metode deskriptif melalui teknik wawancara, check-list dan kuisioner WHOQoL untuk pengukuran kualitas hidup. Pengambilan data menggunakan data primer dengan wawancara terhadap 40 informan dan pengisian kuesioner WHOQoL pada 262 peserta Prolanis. Sedangkan data sekunder diperoleh dari aplikasi P-Care puskesmas. Analisis hasil menggunakan analisa deskriptif dengan pemaparan berupa narasi disertai tabel data.

\section{HASIL}

Dalam penelitian dihasilkan data sebagai berikut, untuk Jenis Kegiatan Prolanis yang 
dilakukan di puskesmas Kota Bengkulu meliputi Kegiatan Konsultasi Medis dan Kegiatan Pemantauan Kesehatan yang sudah dilakukan oleh seluruh puskesmas yang ada di Kota Bengkulu sedang Kegiatan Senam, Kegiatan Edukasi Obat, Kegiatan Home Visit dan Kegiatan SMS Gateway sudah dilakukan oleh $80 \%$ dari seluruh jumlah puskesmas yang ada di Kota Bengkulu.

Seluruh fasilitas kesehatan tingkat pertama (FKTP) milik pemerintah di Kota Bengkulu sejak tahun 2016 wajib melakukan kegiatan Prolanis.Hal ini dikarenakan Prolanis menjadi salah satu indikator kapitasi berbasis pemenuhan komitmen pelayanan untuk puskesmas selain angka kontak dan angka rujukan. Pada pelaksanaan ini ditemukan beberapa pelaksanaan kegiatan yang tidak sesuai dengan SPO yang ada sehingga menimbulkan hambatan untuk proses pelaksanaan kegiatan Prolanis yang efektif. Penyimpanganpenyimpangan ini ditemukan di beberapa puskesmas antara lain penerimaan obat Prolanis yang tidak dilakukan oleh bagian farmasi puskesmas, penyimpanan obat Prolanis tidak diletakkan di apotek puskesmas, kurangnya koordinasi antara penanggung jawab Prolanis dan bagian farmasi dalam pendistribusian obat Prolanis, adanya biaya yang harus dikeluarkan peserta Prolanis dengan penyakit kronis diabetes melitus untuk pemeriksaan gula darah, sering terlambatnya pencairan dana kegiatan Prolanis oleh BPJS Kesehatan yang menyebabkan terhambatnya pelaksanaan kegiatan Prolanis.

Dari data sekunder puskesmas diperoleh hasil penilaian rasio peserta Prolanis rutin berkunjung ke 20 puskesmas di Kota Bengkulu. Beberapa puskesmas memiliki nilai rasio di bawah 50\% yang menyebabkan puskesmas berada di zona tidak aman sehingga akan mempengaruhi nilai kapitasi yang diperoleh oleh puskesmas. Dari pengisian kuesioner kualitas hidup WHOQoL diperoleh hasil sebanyak 262 orang terbagi menjadi 81 responden laki-laki dengan 76 orang yang memiliki kualitas hidup baik dan 5 orang yang memiliki kualitas hidup kurang baik. Sedangkan 181 orang responden perempuan diperoleh 173 orang yang memiliki kualitas hidup baik dan 8 orang yang memiliki kualitas hidup kurang baik. Dari penghitungan nilai kuesioner WHOQoL diperoleh 95,04\% memiliki kualitas hidup yang cukup baik.

\section{PEMBAHASAN}

\section{Jenis Kegiatan Prolanis}

Dalam pelaksanaan Kegiatan Senam Pronalis dari 20 puskesmas di Kota Bengkulu terdapat 4 puskesmas yang belum melaksanakan senam Prolanis.Hal ini disebabkan 
puskesmas merasa kesulitan mengumpulkan peserta Prolanis untuk mengikuti senam karena alasan kesibukan peserta Prolanis pada pagi hari. Untuk itu diperlukan kembali upaya dari puskesmas untuk memberikan edukasi kepada peserta tentang pentingnya aktifitas fisik seperti senam untuk menjaga stabilnya kondisi kesehatan para peserta Prolanis seperti tekanan darah penderita hipertensi dan kadar gula darah penderita DM. Banyak bukti baik penelitian maupun klinis, menunjukkan latihan fisik sebagai obat ampuh untuk pencegahan dan pengelolaan penyakit kronis seperti diabetes. Latihan fisik secara aktif, dapat mencegah $50 \%$ pasien penyakit kronis maju ke DM Tipe 2 jika mereka memenuhi pedoman aktivitas fisik (Newton, 2011). Penyandang hipertensi yang mengikuti kegiatan senam Prolanis selama 4 minggu berturut-turut juga akan mengalami penurunan bermakna pada tekanan darah sistolik dan diastoliknya. Olahraga dapat menyebabkan dilatasi pembuluh-pembuluh darah sehingga tekanan darah menurun (Lumempouw, 2016).

Kegiatan edukasi bagi peserta Prolanis ini dilaksanakan 1 bulan sekali di masingmasing puskesmas.Biasanya kegiatan edukasi ini dilaksanakan setelah pelaksanaan senam Prolanis oleh dokter puskesmas.Pemberian edukasi ini merupakan salah satu upaya preventif yang dilakukan oleh puskesmas untuk penderita penyakit kronis.Edukasi ini bertujuan untuk memberi pengetahuan lebih mendalam tentang penyakit hipertensi dan DM yang mereka derita, sehingga dapat mencegah timbulnya komplikasi penyakit baru bagi peserta Prolanis. Jika sudah sampai pada komplikasi, maka akan membutuhkan biaya yang tinggi untuk pengobatannya, serta menurunkan produktifitas dari penderita.

Konsultasi diperlukan agar tenaga medis dapat memantau kondisi kesehatan peserta Prolanis dan memastikan obat-obat yang rutin mereka minum belum memerlukan penggantian dosis atau penggantian jenis obat.Jika dalam pemeriksaan oleh dokter ditemukan beberapa gejala yang memerlukan perubahan dosis atau pergantian obat maka puskesmas dapat segera melakukan rujukan ke fasilitas kesehatan tingkat lanjutan (FKTL) untuk dilakukan pemeriksaan lanjutan oleh dokter spesialis dan mendapatkan terapi pengobatan baru sesuai dengan kondisi penyakit peserta Prolanis.

Pemantauan kesehatan dilakukan rutin setiap minggu setelah pelaksanaan senam Prolanis untuk pasien hipertensi.Dari beberapa penelitian menunjukkan kegiatan Prolanis mampu mengontrol tekanan darah peserta Prolanis. Dalam penelitian Syuadzah dinyatakan bahwa terdapat hubungan antara tingkat kepatuhan mengikuti kegiatan Prolanis pada pasien Diabetes Mellitus tipe 2 dengan kadar HbA1C. Hal ini menunjukkan bahwa dengan rutin mengikuti kegiatan Prolanis kadar gula darah peserta Prolanis dengan DM dapat terkontrol dengan baik dan diharapkan dapat menghindarkan dari terjadinya komplikasi penyakit lain 
akibat DM.

Beberapa puskesmas yang memiliki call center aktif melakukan kegiatan reminder melalui SMS untuk menginformasikan kepada peserta Prolanis pelaksanaan senam Prolanis, edukasi dan pemantauan kesehatan berupa pemeriksaan tekanan darah dan pemeriksaan kadar gula darah. Hal ini bertujuan agar angka kontak peserta Prolanis dapat tetap terjaga. Beberapa puskesmas belum bisa melaksanakan karena terkendala tidak adanya call center puskesmas.Dalam buku panduan praktis yang dikeluarkan BPJS Kesehatan, home visit dilakukan dengan sasaran peserta baru terdaftar, peserta yang tidak hadir terapi di puskesmas 3 bulan berturut-turut, peserta dengan tekanan darah tidak terkontrol 3 bulan berturut-turut, peserta dengan GDP/GDPP di bawah standar 3 bulan berturut-turut dan peserta pasca opname.

Berdasarkan Permenkes No. 28 Tahun 2014 Bab IV ayat (7), program rujuk balik pada penyakit-penyakit kronis termasuk di dalamnya DM dan hipertensi wajib dilakukan bila kondisi pasien sudah dalam keadaan stabil, disertai dengan surat keterangan rujuk balik yang dibuat oleh dokter spesialis atau subspesialis. Peserta PRB dengan DM dan hipertensi dilakukan pennganan khusus melalui Prolanis.

\section{Pelaksanaan dan Hambatan Prolanis}

Sejak tahun 2016 seluruh puskesmas di Kota Bengkulu wajib melaksanakan Prolanis.Beberapa puskesmas belum melaksanakan seluruh kegiatan sehingga pelaksanaan Prolanis belum berjalan secara optimal. Hal ini terjadi karena adanya beberapa hambatan, yaitu :

a. Penerimaan obat Prolanis tidak dilakukan oleh bagian farmasi puskesmas; Penerimaan obat Prolanis dari apotek kerja sama BPJS Kesehatan yang seharusnya diserah terimakan kepada penanggung jawab farmasi dilakukan oleh penanggung jawab Prolanis yang memiliki pendidikan bukan sebagai tenaga farmasi. Penandatanganan dokumen serah terima obat Prolanis juga dilakukan bukan oleh tenaga kefarmasian. Hal ini bertentangan dengan Peraturan Menteri Kesehatan (2016), yang menyatakan bahwa penanggung jawab farmasi mempunyai tugas dan tanggung jawab untuk menjamin terlaksananya pengelolaan sediaan farmasi dan bahan medis habis pakai yang meliputi perencanaan, permintaan, penerimaan, penyimpanan, pendistribusian, pemusnahan dan penarikan, pengendalian, administrasi dan pemantauan dan evaluasi pengelolaan sediaan farmasi dan bahan medis habis pakai.

b. Penyimpanan obat Prolanis tidak diletakkan di apotek puskesmas; Beberapa puskesmas 
melakukan penyimpanan obat Prolanis di lemari penyimpanan poli umum puskesmas yang bercampur dengan barang-barang poli umum lainnya. Hal ini terjadi karena kurang harmonisnya hubungan antara penanggung jawab prolanis dan penanggung jawab farmasi di puskesmas. Penanggung jawab farmasi merasa tidak pernah dilibatkan dalam kegiatan Prolanis sehingga merasa obat Prolanis adalah tanggung jawab pemegang program Prolanis. Dalam pelaksanaan standar pelayanan kefarmasian di puskesmas, yang diberikan kewenangan untuk bertanggung jawab dalam menjamin terlaksananya pengelolaan sediaan farmasi dan bahan medis habis pakai yang meliputi antara lain penerimaan dan penyimpanan sediaan farmasi dan bahan medis habis pakai adalah seorang kepala ruang farmasi. Selain itu ruang penyimpanan obat dan bahan medis habis pakai harus memperhatikan kondisi sanitasi, temperatur, kelembaban, ventilasi, pemisahan untuk menjamin mutu produk (Kemenkes, 2016).

c. Kurangnya koordinasi antara penanggung jawab Prolanis dan bagian farmasi dalam pendistribusian obat Prolanis; Ada dua puskesmas yang belum melakukan pendistribusian obat Prolanis dengan benar. Pendistribusian obat dilakukan oleh tenaga kesehatan lain bukan tenaga farmasi dan penyerahan tidak dilakukan di apotek puskesmas. Dalam standar pelayanan kefarmasian di puskesmas dinyatakan bahwa seorang kepala ruang farmasi di puskesmas mempunyai tugas dan tanggung jawab untuk menjamin terlaksananya pengelolaan sediaan farmasi dan bahan medis habis pakai, diantaranya pendistribusian sediaan farmasi dan bahan medis habis pakai (Kemenkes, 2016).

d. Adanya biaya yang harus dikeluarkan peserta Prolanis untuk pemeriksaan gula darah; Di beberapa puskesmas masih ditemukan adanya penarikan biaya untuk pemeriksaan gula darah bagi peserta Prolanis penderita diabetes melitus. Hal ini menjadi keluhan tersendiri bagi pasien. Berdasarkan Surat BPJS Kesehatan Bengkulu No. 998/III-05/0615 perihal pemeriksaan penunjang bagi peserta PRB dijelaskan bahwa pelayanan pemeriksaan penunjang program rujuk balik (PRB) yang dijamin oleh BPJS Kesehatan adalah pemeriksaan gula darah puasa/prandial (GDP), gula darah post prandial (GDPP) dan gula darah sewaktu (GDS). Tarif pemeriksaan GDS, GDP, GDPP berdasarkan kesepakatan antara BPJS Kesehatan dengan ADINKES Propinsi Bengkulu sebesar Rp 12.500. Dalam peraturan Kemenkes (2014) disebutkan bahwa ada standar tarif pelayanan kesehatan dalam pelaksanaan JKN, dan puskesmas tidak boleh lagi melakukan penarikan biaya untuk pemeriksaan gula darah untuk peserta Prolanis PRB

e. Terlambatnya pencairan dana kegiatan Prolanis oleh BPJS Kesehatan; Dana Prolanis dalam pelaksanaannya tidak masuk dalam dana kapitasi yang diperoleh oleh puskesmas, 
tetapi dengan sistem pengklaiman pelaksanaan kegiatan. Jadi setelah kegiatan dilaksanakan, puskesmas dapat mengajukan surat pertanggung jawaban (SPJ) untuk pencairan dana ke BPJS Kesehatan. BPJS Kesehatan akan melakukan verivikasi SPJ dengan SPO waktu verivikasi selama 15 hari. Setelah lolos verivikasi dana akan ditransfer ke rekening penanggung jawab Prolanis.Dalam pelaksanaannya tiga bulan terakhir ini dana Prolanis belum masuk ke rekening penanggung jawab Prolanis. Permasalahan dana ini tentu saja harus ada segera solusinya, karena hal ini membuat dismotivasi beberapa penanggung jawab Prolanis di puskesmas.

\section{Rasio Peserta Prolanis Rutin Berkunjung ke FKTP}

Jumlah peserta Prolanis rutin berkunjung ke FKTP adalah jumlah peserta JKN yang terdaftar dalam Prolanis (per nomor identitas peserta) yang mendapatkan pelayanan kesehatan di FKTP per bulan, baik di dalam gedung maupun di luar gedung, tanpa memperhitungkan frekuensi kedatangan peserta dalam satu bulan.Jumlah peserta Prolanis rutin berkunjung ini dihitung jika peserta mengikuti salah satu atau lebih kegiatan Prolanis, seperti edukasi klub, konsultasi medis, pemantauan kesehatan melalui pemeriksaan penunjang, senam Prolanis, home visit dan pelayanan obat secara rutin (obat PRB).Hasil persentase rasio kunjungan peserta Prolanis ini mempengaruhi nilai kapitasi yang puskesmas terima. Jika nilai rasio ini di atas 50\% maka puskesmas berada di zona aman, sedangkan jika nilai rasio ini di bawah 50\% maka puskesmas berada di zona tidak aman untuk indikator Prolanis. Jika salah satu indikator dari ketiga indikator yaitu angka kontak, rasio rujukan rawat jalan non spesialistik dan rasio peserta Prolanis rutin berkunjung ke FKTP berada di zona tidak aman, maka puskesmas akan memperoleh pembayaran kapitasi hanya sebesar 95\% dari keseluruhan pembayaran yang seharusnya puskesmas terima. Hal ini tentu saja akan menimbulkan dampak kerugian bagi puskesmas karena akan mengurangi pendapatan jasa tenaga medis maupun dana operasional puskesmas.

Dalam penelitian Syuadzah dinyatakan bahwa terdapat hubungan antara tingkat kepatuhan mengikuti kegiatan Prolanis pada pasien Diabetes Mellitus tipe 2 dengan kadar HbA1C. Hal ini menunjukkan bahwa dengan rutin mengikuti kegiatan Prolanis kadar gula darah peserta Prolanis dengan DM dapat terkontrol dengan baik dan diharapkan dapat menghindarkan dari terjadinya komplikasi penyakit lain akibat DM.

\section{Kualitas Hidup Peserta Prolanis}

Berdasarkan data yang diperoleh menggunakan instrument berupa kuesioner 
WHOQOL-BREF (Mardiati, 2004), diperoleh pengukuran kualitas hidup peserta Prolanis sebesar 95,04\% responden dengan kualitas hidup yang baik. Hal ini dipengaruhi beberapa faktor pendukung antara lain puskesmas melakukan penjaringan benar-benar hanya untuk peserta Prolanis yang benar-benar mau mengikuti semua kegiatan Prolanis dan yang memiliki semangat tinggi untuk menjaga kesehatannya. Dengan adanya karakteristik ini, dalam penilaian kualitas hidup sebagian besar peserta Prolanis menganggap penyakit DM dan hipertensi ini bukanlah suatu beban dalam hidup mereka sehingga tidak mengganggu aktivitas mereka sehari-hari. Selain itu, kegiatan Prolanis seperti pelaksanaan senam bugar lansia memberikan pengaruh terhadap peningkatan kualitas baik hidup lansia usia 60 tahun keatas (Pamungkas,2016).

Penderita penyakit kronis seperti DM type 2 memiliki stres yang tinggi, yang tentunya akan mempengaruhi fungsi tubuh. Stres akan memicu peningkatan kortisol dalam tubuh yang akan mempengaruhi peningkatan kadar glukosa darah dengan meningkatkan glukoneogenesis katabolisme lemak dan protein. Selain itu, kortisol juga akan mengganggu ambilan glukosa oleh sel tubuh sehingga dapat mempengaruhi kadar glukosa darah. Kondisi ini dapat menyebabkan ketidak seimbangan kadar gula dalam darah. Hal ini jika dialami dalam waktu yang lama akan mempengaruhi kualitas hidup penderita DM type 2. (Antari, 2012). Diabetes adalah kondisi seumur hidup yang jika dikelola dengan buruk dapat diprediksi akanmeningkatkan komplikasi dan kecacatan. Sebaliknya, jika diabetes dikelola dengan baik, kejadian komplikasi dapat dikurangi secara signifikan (Lewanczuk, 2009).Dalam penelitian Syuadzah (2015), dinyatakan bahwa terdapat hubungan antara tingkat kepatuhan mengikuti kegiatan Prolanis pada pasien Diabetes Mellitus tipe 2 dengan kadar HbA1C. Hal ini menunjukkan bahwa dengan rutin mengikuti kegiatan Prolanis kadar gula darah peserta Prolanis dengan DM dapat terkontrol dengan baik dan diharapkan dapat menghindarkan dari terjadinya komplikasi penyakit lain akibat DM sehingga kualitas hidup penderita DM dapat meningkat.

\section{KESIMPULAN}

Berdasarkan hasil dan pembahasan Evaluasi Penatalaksanaan Prolanis Sebagai Indikator KapitasiBerbasis Pemenuhan Komitmen Pelayanan Di PuskesmasKota Bengkulu dapat disimpulkan bahwa 20\% puskesmas di Kota Bengkulu belum melaksanakan seluruh kegiatan Prolanis dengan optimal. Hal ini tentu saja akan menghambat tujuan dari penyelenggaraan Program Pengelolaan Penyakit Kronis yang diselenggarakan oleh BPJS Kesehatan di fasilitas kesehatan primer dalam peningkatan mutu pelayanan kesehatan dan 
dalam upaya pengendalian biaya pelayanan kesehatan pada penderita penyakit kronis.

\section{DAFTAR PUSTAKA}

Antari, G. 2012. Besar Pengaruh Dukungan Sosial Terhadap Kualitas Hidup Pada Penderita Diabetes Melitus Tipe 2 Di Poliklinik Interna RSUP Sanglah. Tesis

Badan Penyelenggara Jaminan Sosial Kesehatan.2014,Panduan Praktis Prolanis (Program Pengelolaan Penyakit Kronis), Jakarta, BPJS Kesehatan Republik Indonesia.

Badan Penyelenggara Jaminan Sosial Kesehatan. 2015, Peraturan Badan Penyelenggara Jaminan Sosial Kesehatan Nomor 2 Tahun 2015 Tentang Norma Penetapan Besaran Kapitasi dan Pembayaran Kapitasi Berbasis Pemenuhan Komitmen Pelayanan Pada Fasilitas Kesehatan Tingkat Pertama, Jakarta, BPJS Kesehatan Republik Indonesia.

Badan Penyelenggara Jaminan Sosial Kesehatan. 2017, Peraturan Bersama Sekretaris Jenderal Kementerian Kesehatan Republik Indonesia dan Direktur Utama Badan Penyelenggara Jaminan Sosial KesehatanNo.Hk.01.08/III/980/2017 No. 2 Tahun 2017 Tentang Petunjuk Teknis Pelaksanaan Pembayaran Kapitasi Berbasis Pemenuhan Komitmen Pelayanan Pada Fasilitas Kesehatan Tingkat Pertama, Jakarta, BPJS Kesehatan Republik Indonesia.

Dennis, S.M., Zwar, N., Griffiths, R., Roland, M., Hasan, I., Davies, G.P., et al. 2008, Chronic Disease Management In Primary Care: From Evidence To Policy, The Medical Journal of Australia, 188 (8 Suppl): S53.

Idris, F. 2014, Pengintegrasian Program Preventif Penyakit Diabetes Melitus Tipe 2 PT Askes (Persero) ke Badan Penyelenggara Jaminan Sosial Kesehatan (BPJS Kesehatan), J Indon Med Assoc, 64: 3.

Kementerian Kesehatan. 2014, Peraturan Menteri KesehatanRepublik Indonesia Nomor 59 Tahun 2014, tentang Standar Tarif Pelayanan Kesehatan Dalam Penyelenggaraan Program Jaminan Kesehatan, Jakarta, Kementerian Kesehatan Republik Indonesia.

Kementerian Kesehatan. 2016, Peraturan Menteri KesehatanRepublik Indonesia Nomor 74 Tahun 2016, tentang Standar Pelayanan Kefarmasian di Puskesmas, Jakarta, Kementerian Kesehatan Republik Indonesia.

Lewanczuk, R. 2009, Diabetes and Chronic Disease Management, Canadian Journal of Diabetes, 33: 352-353.

Lumempouw, Wungouw. dan Polii. 2016, Pengaruh Senam Prolanis Terhadap Penyandang Hipertensi, Jurnal e-Biomedik (eBm), 4: 1.

Mardiati, R. and Joewana, S. 2004, Translation of The World Health Organization Quality of Life (WHOQOL)-BREF, Jakarta, Universitas Katolik Atma Jaya.

Newton, R. 2011, Exercise is medicine for chronic disease management, Journal of Science and Medicine in Sport, 14: e15.

Pamungkas dan Kumaat.2016. Pengaruh Senam Bugar Lansia Terhadap Kualitas Hidup Lansia Usia 60 Tahun Keatas di Posyandu Lansia Karang Werdha Kedurus Surabaya. Jurnal Kesehatan Olahraga, 06 (2): 254-257.

Singh, D. 2008,Policy Brief - How Can Chronic Disease Management Programmes Operate Across Care Settings and Providers?, WHO European Ministerial Conference on Health Systems, Tallinn Estonia. 
Stellefson, M. Dipnarine,K. and Stopka, C.2013,The Chronic Care Model and Diabetes Management in US Primary Care Settings: A Systematic Review, Centers for Disease Control and Prevention, 10.

Syuadzah, R. 2015, 'Hubungan antara Tingkat Kepatuhan Mengikuti Kegiatan Prolanis pada Pasien Diabetes Mellitus Tipe 2 dengan Kadar HbA1C', Tesis, M. Kes, Fakultas Kedokteran, Universitas Sebelas Maret, Surakarta.

World Health Organization.1996, World Health Organization Quality of Life QuestionnaireShort Version (WHOQOL), WHO. 